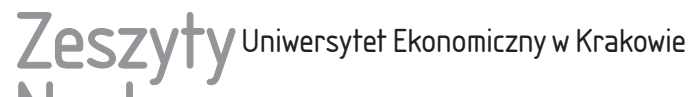 Naukowe
}

Anna Jędrzychowska

Katedra Ubezpieczeń

Uniwersytet Ekonomiczny we Wrocławiu

Radostaw Pietrzyk

Katedra Inwestycji Finansowych i Zarządzania Ryzykiem

Uniwersytet Ekonomiczny we Wrocławiu

\section{Miarkowanie odszkodowania za utracone dochody z wykorzystaniem prognozy dochodów}

\section{Streszczenie}

Wysokość odszkodowania, które powinna otrzymać osoba poszkodowana, składa się z kilku elementów. Jednym z nich, gdy poszkodowany nie jest zdolny do pracy, jest wysokość dochodów, które utracił. Aby odszkodowanie było dobrze ustalone, warto posłużyć się w jego ustalaniu wartością pieniądza w czasie i dynamiką wzrostu wynagrodzeń w sektorze, w którym pracował poszkodowany. Należy również wziąć pod uwagę inflację.

W artykule przeprowadzono symulacje pokazujące różnice między podejściem, które nie uwzględnia wymienionych czynników, a podejściem, które te czynniki uwzględnia. Pierwsze podejście jest często używane przez polski wymiar sprawiedliwości w ustalaniu wysokości renty odszkodowawczej. Drugie jest propozycją lepszego zabezpieczenia osoby poszkodowanej, która utraciła zdolność do pracy.

Słowa kluczowe: renta, świadczenie odszkodowawcze, finanse osobiste, szkody osobowe. 


\section{Wprowadzenie}

Prawo cywilne (w Polsce spisane w ustawie Kodeks cywilny) przewiduje, że każdy poszkodowany $\mathrm{z}$ winy innego może domagać się zadośćuczynienia w formie pieniężnego odszkodowania. W szczególności dotyczy to utraty dóbr majątkowych i osobistych, a źródłem strat może być tak szkoda na osobie, jak i na mieniu. Jednym z typów tych odszkodowań są odszkodowania za utratę przyszłych dochodów. Wysokość tego odszkodowania mierzona jest jako suma dochodów w przyszłości, które byłyby dostępne dla poszkodowanego, w sytuacji gdyby szkoda nie nastąpiła.

W polskich sądach szkody w odniesieniu do utraty przyszłych dochodów są szacowane intuicyjnie i nie są ilościowo odnoszone do sytuacji gospodarczej. Ponadto świadczenia przyznawane z tytułu utraconych dochodów najczęściej nie uwzględniają wartości pieniądza w czasie i ewentualnego realnego wzrostu dochodów poszkodowanego w przypadku niewystąpienia zdarzenia rodzącego odpowiedzialność cywilną sprawcy. Zasadne zatem jest indeksowanie świadczenia w celu zachowania jego realnej wartości. Niemniej ważne jest również utrzymanie standardu życia poszkodowanego przed zdarzeniem, jak również wyrównanie przyrostu jego dochodu, jaki mógłby mieć miejsce, gdyby do zdarzenia nie doszło.

Wiążą się z tym co najmniej dwa wyzwania. Pierwsze z nich dotyczy właściwego ustalenia rodzaju indeksacji świadczenia, drugie - ustalenia obecnej wartości przyznanego świadczenia rentowego z powodu działania czynników ryzyka, takich jak długość życia poszkodowanego czy zmienność wskaźników wzrostu świadczenia.

Celem niniejszego artykułu jest pokazanie wagi problemu przyznawania rentowych świadczeń odszkodowawczych z tytułu utraconych dochodów i skutków ich niewłaściwego szacowania, jak również przedstawienie propozycji zobiektywizowanego systemu ich ustalania.

\section{Przegląd rozwiązań stosowanych na świecie}

W tej części zaprezentowano krótkie opisy rozwiązań stosowanych w omawianym obszarze w Wielkiej Brytanii i Stanach Zjednoczonych. W pierwszym z systemów (podobnie jak w Polsce) zdecydowanie popiera się wypłaty dla poszkodowanego w systemie renty, zaś w drugim - wypłatę jednorazową opartą na wartości obecnej świadczenia rentowego.

Wielka Brytania jest przykładem kraju, który w kalkulacji strat ekonomicznych przyjął zestaw mnożników opartych na podstawach aktuarialnych. Brak 
spójności w zasądzanych wyrokach doprowadził do powołania w latach 70. i 80. $\mathrm{XX}$ w. komisji, której celem było wprowadzenie reformy i wsparcie wyceny strat aktuarialną bazą. W efekcie prac reformatorskich w 1984 r. ukazało się pierwsze wydanie tablic Ogdena (The Ogden Tables - Actuarial Tables with explanatory notes for use in Personal Injury and Fatal Accident Cases). Mają one być pomocą dla tych, którzy szacują ryczałtową kwotę mającą stanowić odpowiednią rekompensatę za powstałe w konsekwencji szkody na osobie straty majątkowe - głównie utracone dochody i koszty wtórne, jak również koszty opieki ${ }^{1}$. Tabele zostały przygotowane przez grupę roboczą pod przewodnictwem sir Michela Ogdena, obejmującą aktuariuszy i prawników pracujących w ramach Government Actuary's Department. Koncepcja tabel opiera się na czynnikach zwanych mnożnikami, które są wykorzystywane do ustalenia ryczałtowego ekwiwalentu skapitalizowanej wartości bieżącej przyszłych strat w ujęciu rocznym (netto w przypadku utraconych zarobków i emerytur). Mnożniki oparte są na prognozach przyszłych współczynników umieralności ludności w Wielkiej Brytanii oraz ewentualnie także innych czynników dyskontujących, wpływających na ryzyko śmiertelności.

Od tego czasu tworzono kolejne, udoskonalane wydania tablic (w $2011 \mathrm{r}$. ukazało się siódme wydanie), nad którymi pracowały interdyscyplinarne grupy aktuariuszy, prawników, księgowych i ubezpieczycieli. Sędziowie nie byli zobowiązani do korzystania z tablic Ogdena aż do 1999 r., kiedy to Izba Lordów zatwierdziła tablice jako podstawową metodę obliczania przyszłej straty majątkowej i postawiła wymaganie, by sędziowie używali tablic w ustalaniu swojej opinii.

Tabele przez lata wymagały modyfikacji i ulepszeń zgodnie z obserwowanymi problemami wynikającymi z ich stosowania w praktyce i analizami ekonomistów. Pierwsze wydanie nie uwzględniało ryzyka utraty zatrudnienia i zróżnicowań regionalnych, a jedynie ryzyko śmierci. W następnych edycjach uwzględniono takie czynniki korygujące, jak: ryzyko bezrobocia, zróżnicowanie terytorialne aktywności gospodarczej, wiek, choroby czy edukacja. Uaktualniano także założenia dotyczące dalszego trwania życia. Tabele edycji siódmej (z 2011 r.) nie uwzględniają jednak innych czynników ryzyka i zmiennych kolei życia, takich jak możliwość, że poszkodowany będzie okresowo pozostawał bez dochodów z powodu złego stanu zdrowia lub utraty pracy czy opieki nad dziećmi. Tym samym zwraca się uwagę, że tablice mimo wielu modyfikacji wciąż mają pewne niedoskonałości i ograniczenia. W literaturze znaleźć można polemikę z tą metodą, np. w pracach: [Luckett i Craner 1994, Haberman i Bloomfield 1990, Ritchie 1994].

110 października 2011 r. opublikowano siódme wydanie tablic Ogdena: http://www.gad.gov. uk/Documents/Other\%20 Services/Ogden\%20Tables/Ogden_Tables_7th_edition.pdf. 
Natomiast w Stanach Zjednoczonych utracone dochody obliczane są co do zasady na podstawie wynagrodzenia brutto, a większość stanów wymaga dyskontowania utraconych zarobków, usług i przyszłych kosztów leczenia do wartości bieżących. W Wielkiej Brytanii istnieje jeden system mnożników bezpośrednio dostępny dla sądu jako baza dla kalkulacji, w Stanach Zjednoczonych zaś kalkulacja dokonywana jest przez ekspertów, tzw. sądowych ekonomistów - głównie z zakresu finansów, aktuariatu i innych (np. psychologów w zakresie szkód niemajątkowych) - indywidualnie dla każdego przypadku i różni się w poszczególnych jurysdykcjach stanowych z uwagi na odrębność regulacji. Pełne opracowanie omawianego systemu prezentuje J.O. Ward [2009], zaś przykłady analiz ekonomicznych dla poszczególnych stanów znaleźć można w pracach: [Kucsma i Tinari 2010, Spizman i Tinari 2011], a także [Anderson i Roberts 1989, Bryan i Linke 1988, Lane i Glennon 1985, Gilbert 1994 i 1997, Thornton, Rodgers i Brookshire 1997, Rodgers, Brookshire i Thornton 1996].

W literaturze podkreśla się, że model wyceny ze Stanów Zjednoczonych skupia się na ustaleniu zadośćuczynienia za uszczerbek w kapitale ludzkim. Dlatego też ustalenie wysokości utraconych dochodów skupia się nie tylko na nominalnej ich wartości, ale również na ich dynamice i utraconych perspektywach ich wzrostu. Podkreśla się więc doświadczenie i ścieżkę zawodową poszkodowanego i wskazuje się na dynamiczny rozkład w czasie dochodów i ich wzrostu wraz z rozwojem pracownika. Podkreśla się również, że czynniki niezwiązane bezpośrednio z poszkodowanym (np. wiek, płeć, edukacja, zawód, doświadczenie, miejsce zamieszkania) oraz rozwój całej gospodarki mają wpływ na dochody, które w przyszłości uzyskiwałby poszkodowany (więcej w: [Nelson i Patton 1990, Mullett, Nelson i Patton 1990, Gohmann, McCrickard i Slesnick 1998]).

Ważnym narzędziem stosowanym w ustalaniu utraconych dochodów są tablice przyszłego trwania pracy zawodowej (worklife table) opublikowane przez Bureau of Labor Statistics (BLS) (por. [Smith 1982]). Tabele te zawierają oszacowanie oczekiwanej liczby lat, które osoba w danym wieku pozostanie na rynku pracy aż do przejścia na emeryturę lub śmierci.

Jakkolwiek nie ma w Stanach Zjednoczonych systemowego modelu ustalania wysokości świadczeń za straty majątkowe na wzór brytyjski, to pewien obraz prób poszukiwania rozwiązań systemowych dają specjalne plany kompensacji szkód wynikających ze zdarzeń, w których liczba poszkodowanych była znaczna (katastrofy, szkody wyrządzone przez produkt niebezpieczny). Plany te mają na celu zmniejszenie liczby procesów sądowych. Opierają się na standaryzacji świadczeń, ujednoliceniu zasad ich przyznawania. Dotyczą strat o charakterze majątkowym i niemajątkowym. Kompensację ustala się często w uproszczony sposób ryczałtowy, czasem też bez rozdzielenia poszczególnych składowych. 
Więcej informacji na temat wspomnianych planów znaleźć można w pracy R. Minnechan [2009]. Przykładem planu kompensacyjnego zawierającego wyodrębniony moduł kalkulacji strat majątkowych, które okazały się dużo bardziej znaczącą co do wartości pozycją w świadczeniach, był Fundusz Odszkodowań dla Ofiar 11 września 2001 r. (9/11 Victim Compensation Fund - VCF; zob. [Tinari, Cahill i Grivoyannis 2006]). Kompensacja - obejmująca szkody tak o charakterze majątkowym, jak i niemajątkowym - warunkowana była zrzeczeniem się prawa do pozwania amerykańskich podmiotów takich jak linie lotnicze. Fundusz był jednym z elementów szerszego projektu wprowadzonego ustawą Air Transportation Safety and System Stabilization Act, który miał stanowić alternatywny system kompensacji w sektorze przewozów lotniczych po atakach terrorystycznych z 2001 r., z założenia bez konieczności wykazywania winy. W zakresie strat o charakterze majątkowym kompensacja opierała się na kwantyfikacji utraty przyszłych zarobków lub świadczeń emerytalnych, tak w przypadku śmierci, jak i obrażeń ciała czy rozstroju zdrowia. Świadczenia standaryzowano przez ustalenie pięciu tabel określających domniemany poziom należnego skumulowanego świadczenia - zależnie od wieku, dochodów i wielkości gospodarstwa domowego, z wykorzystaniem standardowych wskaźników wzrostu i stóp dyskontowych.

Warto dodać, że J.O. Ward [2009] dokonuje też porównania wyników kalkulacji na podstawie dwóch źródeł: tablic Ogdena (edycja szósta) i tablic funduszu VCF. Wnioski z porównania, które wynikają z zakresu uwzględnianych czynników, są takie, że tabele VCF i tablice Ogdena nie uwzględniają wykształcenia, a tablice Ogdena dodatkowo bezrobocia i wpływu niepełnosprawności na cyk1 życia zawodowego. W ocenie J.O. Warda tablice Ogdena wydają się nie w pełni kompensować straty w przypadku osób młodych, a przewartościowywać straty w przypadku starszych pracowników. J.O. Ward podkreśla też, że o ile tablice zapewniają przewidywalność i spójność, o tyle mocną stroną amerykańskiej metodologii kalkulacji jest to, że była przedmiotem badań ekonomistów „w tyglu sali sądowej”, a jej koncepcje są tematem bieżącej debaty i podlegają publicznej krytyce (por. [Lewis i in. 2002]).

\section{Charakterystyka badania i zastosowane metody badawcze}

Do ustalania wielkości świadczenia z tytułu utraconych dochodów dla osoby poszkodowanej wykorzystuje się najczęściej model renty dożywotniej. Świadczenie to powinno pokrywać wszystkie utracone dochody oraz zwiększone koszty utrzymania poszkodowanego. W niniejszym artykule rozważania zostaną przeprowadzone wyłącznie w odniesieniu do utraconych dochodów. 
Należy pamiętać, że świadczenie powinno pokrywać jedynie różnice pomiędzy dotychczasowym poziomem dochodu netto a świadczeniami wypłacanymi np. z systemu ubezpieczeń społecznych (np. renta z tytułu niezdolności do pracy). Ciężar wypłaty przyznanego świadczenia spoczywa na sprawcy szkody, chyba że posiada on ubezpieczenie od odpowiedzialności cywilnej, kiedy to zobowiązanie zostaje przejęte przez ubezpieczyciela (do wysokości sumy gwarancyjnej).

Podstawę ustalenia wartości przyznanej renty stanowić powinny dwie składowe: wysokość miesięcznego świadczenia oraz sposób indeksowania. Podstawę naliczenia miesięcznego świadczenia w tej rencie stanowić mogą co do zasady:

- w przypadku osoby zatrudnionej - jej dotychczasowe wynagrodzenie netto lub ubytek wynagrodzenia w przypadku utraty jego części;

- w przypadku osoby pracującej na podstawie zawartych umów cywilnoprawnych, samozatrudnionej, prowadzącej działalność gospodarczą lub gospodarstwo rolne - jej uśredniony miesięczny dochód netto z tej działalności (np. średnia z ostatniego roku lub z okresu dłuższego, jeżeli poszkodowany wskazał okoliczności to uzasadniające);

- w przypadku osób nieposiadających dochodów (np. bezrobotnych, bez kwalifikacji) - świadczenie równe minimalnej płacy netto w gospodarce;

- w przypadku osób małoletnich, uczących się - świadczenie równe średniemu wynagrodzeniu netto $\mathrm{w}$ gospodarce.

W przypadku osób pochodzących z dwóch pierwszych grup takie podejście wydaje się naturalne i jest powszechnie stosowane, gdyż zdarzenie powodujące niezdolność do pracy nie powinno pogorszyć sytuacji materialnej poszkodowanego. Dyskusyjną kwestią jest określenie wysokości świadczenia dla osób niepracujących. Nie ma bowiem możliwości wskazania wprost wartości utraconych dochodów. Niemniej jednak nie można przyjąć, że osoba ta nie podjęłaby pracy w przyszłości, a bezsprzecznie zdarzenie to uniemożliwi jej to w przyszłości. Dlatego też propozycją może być przyjęcie za podstawę świadczenia minimalnego wynagrodzenia w gospodarce w przypadku osób długotrwale bezrobotnych, a w przypadku osób mających krótkotrwałą przerwę w zatrudnieniu - średnie wynagrodzenie netto, np. z ostatniego rocznego okresu zatrudnienia. Kolejną grupą są osoby małoletnie oraz pełnoletnie uczące się, które nie podjęły jeszcze zatrudnienia. W ich przypadku nie ma możliwości określenia nawet orientacyjnej wielkości dochodów, jakie by osiągały. Nie można też zakładać, że osoby te osiągałyby dochody na najniższym poziomie. Zasadne więc wydaje się przyjęcie za podstawę świadczenia rentowego średniego wynagrodzenia netto w gospodarce.

Podejmując rozważania nad drugim problemem, tj. sposobem indeksowania, należy wskazać, że indeksacja ta powinna utrzymać realną wartość świadczenia rentowego, jak również odzwierciedlać przyszły potencjalny wzrost dochodów netto. Po pierwsze przyznawane świadczenia powinny być zatem kapitalizowane 
stopą inflacji. Nie jest to jednak wystarczające, gdyż należy uwzględnić, że dochody poszkodowanego mogłyby ulegać zmianie, a w szczególności zwiększać swoją realną wartość. Należy zatem w indeksacji uwzględnić również realne tempo wzrostu świadczenia rentowego przez wzięcie pod uwagę tempa wzrostu wynagrodzeń w gospodarce. Tempo to może być jednak odzwierciedlone w różny sposób, w zależności od przynależności poszkodowanego do ww. grup oraz ewentualnie branży, w której był zatrudniony. W przypadku dwóch pierwszych grup za typowe realne tempo wzrostu wynagrodzeń można przyjąć wskaźnik wzrostu płac dla całej gospodarki, natomiast w sytuacji gdy poszkodowany był zatrudniony w specyficznym sektorze gospodarki, dla którego jest publikowany wskaźnik wzrostu płac, wskaźnik dla tego sektora. W przypadku przyznania świadczenia w wysokości minimalnego wynagrodzenia netto w gospodarce tempo wzrostu powinno być zgodne z tempem podwyższania tego wynagrodzenia. W przypadku świadczenia na poziomie średniego wynagrodzenia netto indeksacja powinna być zgodna $\mathrm{z}$ tempem wzrostu tego wynagrodzenia $\mathrm{w}$ gospodarce.

W przypadku zastosowania różnych wskaźników indeksacji konieczne jest również dostosowanie częstotliwości indeksacji świadczenia do tych wskaźników. Część z nich jest podawana w okresach miesięcznych (np. tempo wzrostu wynagrodzeń, inflacja) lub w okresach rocznych (np. wzrost minimalnego wynagrodzenia). W przypadku przyjęcia indeksacji świadczeń rentowych raz w roku konieczne jest zatem przeliczenie miesięcznych wskaźników indeksacji na średnioroczne.

Rentowe świadczenie odszkodowawcze może być wypłacane okresowo lub jednorazowo. W przypadku wypłaty jednorazowej należy przyjąć wartość bieżącą rent okresowych (kapitalizowanych zgodnie z powyższymi propozycjami) wypłacanych do momentu oczekiwanego czasu życia zgodnie z tablicami trwania życia, daną wzorem (1):

$$
P V A_{m}=\left\{\begin{array}{cc}
v^{m} p q \frac{q^{m}-d^{m}}{q-d} & q \neq d, \\
m p & q=d,
\end{array}\right.
$$

gdzie:

$p$ - wartość świadczenia rentowego w pierwszym okresie miesięcznym,

$q=1+i$, gdzie $i-$ miesięczny wskaźnik inflacji,

$d=1+w$, gdzie $w$ - miesięczny wskaźnik wzrostu płac,

$v=1 / q$,

$m$ - liczba miesięcy wypłaty renty.

Problemem takiego sposobu wypłaty jest konieczność określenia długoterminowej prognozy inflacji oraz tempa wzrostu świadczenia, które posłużyłyby 


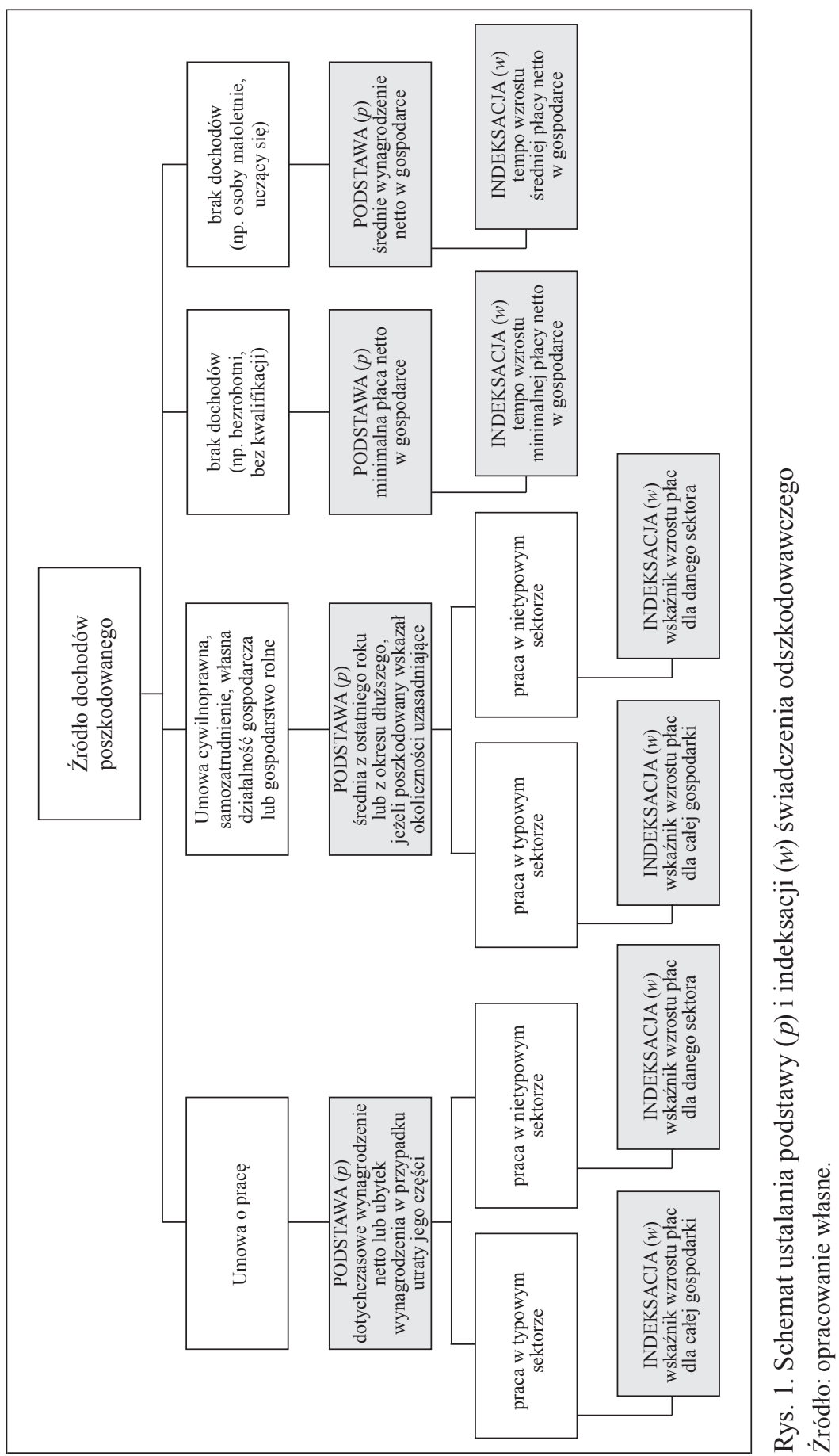


do określenia wartości bieżącej tego świadczenia. W tym celu jako prognozami można posłużyć się oszacowaniami średnich historycznych z długiego okresu. Niemniej jednak w krajach takich jak Polska ze względu na specyfikę ostatnich 25 lat transformacji gospodarczej dane historyczne mogą być nieadekwatne do prognozowania (długoletnia walka z wysoką inflacją oraz wysokie tempo wzrostu płac w gospodarce spowodowane dużą dynamiką rozwoju gospodarczego). Wadami tego sposobu wypłaty dla poszkodowanego mogą być: nieracjonalne wykorzystanie środków ze świadczenia (przedwczesna konsumpcja i niezabezpieczenie środków na przyszłość), utrata stałego dochodu, który to może stanowić podstawę ustalania zdolności kredytowej, ekspozycja na ryzyko długowieczności (życie powyżej wieku, który został wykorzystany w kalkulacji wartości obecnej świadczenia jednorazowego). Wypłata jednorazowa stanowi również pewne zagrożenie dla systemu opieki społecznej, gdyż w przypadku przedwczesnego wyczerpania środków ze świadczenia poszkodowany może stać się beneficjentem tego systemu.

Głównym problemem związanym z okresową wypłatą świadczenia jest niepewność co do całkowitej jego wysokości (nieznany czas wypłat oraz wielkość okresowych świadczeń). Powoduje to konieczność utworzenia rezerw i zarządzania nimi przez zakłady ubezpieczeń. Kolejnym problemem jest możliwość wyczerpania się sumy gwarancyjnej i powrót roszczenia do sprawcy szkody. Sytuacja ta jest o tyle niekorzystna dla poszkodowanego, że sprawca szkody może być w przyszłości niezdolny do dalszego wypłacania świadczenia lub może już nie żyć.

Na rys. 1 zaprezentowano schemat, zgodnie z którym należałoby postępować przy ustalaniu wysokości odszkodowania z tytułu utraconych dochodów. Schemat pozwala na ustalenie dwóch wartości wykorzystywanych we wzorze (1), tj. $p$ i $w$.

\section{Przykłady empiryczne}

Powyższe rozważania zilustrowane zostaną trzema przykładami opartymi na rzeczywistych sprawach odszkodowawczych zaczerpniętych z polskiego systemu sądownictwa. Symulacje opracowane na podstawie tych przykładów mają na celu ukazanie różnicy w wartości świadczeń przyznawanych zgodnie z dotychczasową praktyką sądowniczą oraz propozycją przedstawioną w niniejszym artykule.

Do kalkulacji przyjęto następujące założenia. Za prognozę średniego miesięcznego wzrostu płac w gospodarce przyjęto średni miesięczny wskaźnik wzrostu płac w sektorze przedsiębiorstw oszacowany na podstawie danych historycznych ( $0,373 \%$ miesięcznie). W celu ukazania wartości realnej świadczeń 
wykorzystano długoterminową prognozę inflacji (wskaźnik CPI) przez przyjęcie tego wskaźnika na poziomie celu inflacyjnego określonego przez Radę Polityki Pieniężnej (2,5\% rocznie). W przykładach za wysokość pierwszego miesięcznego świadczenia rentowego przyjęto kwotę przyznaną przez sąd. Pominięto rozważania na temat zasadności jej wielkości.

\section{Przypadek 1}

Przypadek 1 dotyczy utraty dochodów przez 37-letnią kobietę. W chwili wypadku komunikacyjnego była osobą bezrobotną, mającą podjąć pracę jako grafik komputerowy z wynagrodzeniem netto ok. 2000 PLN. Sąd przyznał poszkodowanej rentę z tytułu utraconych dochodów w wysokości 1132 PLN miesięcznie jako uzupełnienie świadczenia rentowego z ZUS wynoszącego 867,18 PLN.

W symulacji przyjęto, że przewidywany dalszy czas trwania życia (zgodnie z tablicami trwania życia) dla tej osoby wynosi 45 lat, a zatem szacowana liczba miesięcy wypłat renty wynosi 540. Na rys. 2 zaprezentowano kształtowanie się wartości realnej przyznanego miesięcznego świadczenia z teoretyczną wartością tego świadczenia kapitalizowanego prognozą miesięcznego wskaźnika wzrostu płac w sektorze przedsiębiorstw.

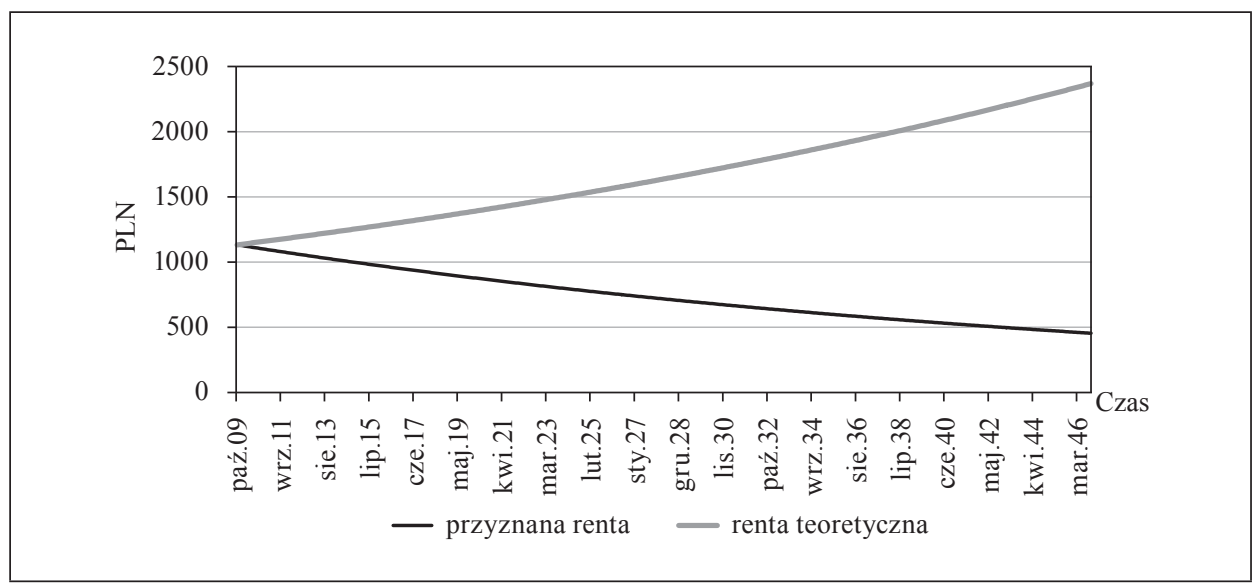

Rys. 2. Wartość realna renty dożywotniej (przypadek 1)

Źródło: opracowanie własne.

Na użytek wypłaty jednorazowej oszacowano wartość obecną świadczenia rentowego. Obliczeń dokonano dla oczekiwanego dalszego trwania życia oraz dyskontując przyszłe wypłaty prognozowanym wskaźnikiem inflacji. Wartość obecna zasądzonej renty wyniosła 369417 PLN, a kapitalizowanej renty teore- 
tycznej 989458 PLN. W rozważanym przykładzie zaniżenie świadczenia w wartościach realnych w skali całego okresu wyniosło 620041 PLN (w odniesieniu do oczekiwanej dalszej długości życia). Narastanie niedoboru prezentuje rys. 3. Brak kapitalizacji renty przyznanej przez sąd skutkuje powstawaniem skumulowanego niedoboru w dochodach gospodarstwa domowego, a co za tym idzie - pogarszanie się standardu życia tego gospodarstwa.

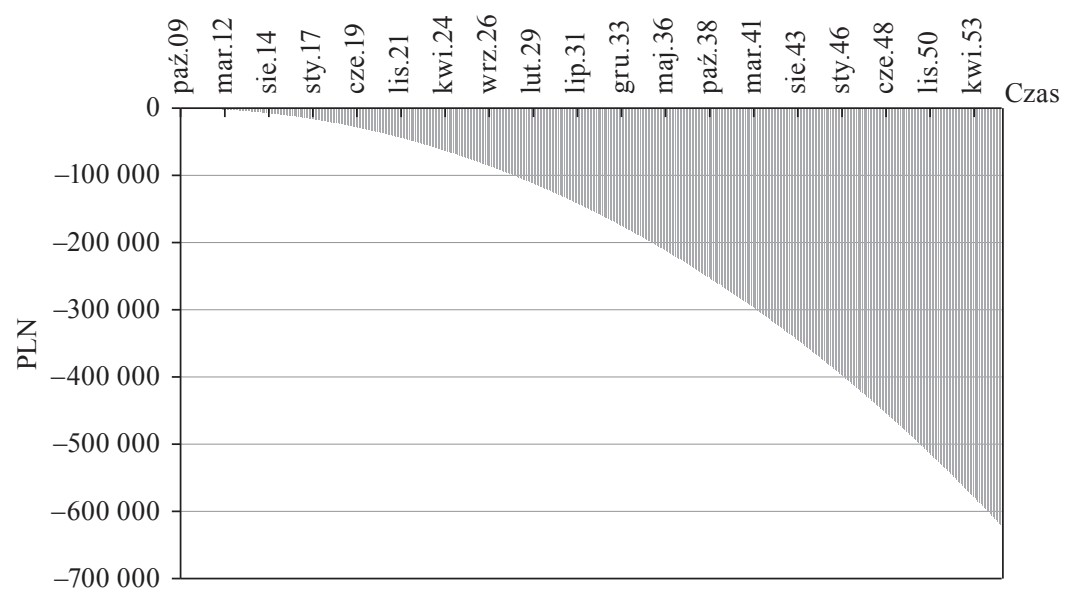

Rys. 3. Skumulowany niedobór z tytułu przyznanej renty (przypadek 1)

Źródło: opracowanie własne.

\section{Przypadek 2}

Bezrobotny, 49-letni mężczyzna na skutek błędu lekarskiego powodującego utratę zdrowia został uznany za niezdolnego do pracy. Złożył wniosek o odszkodowawcze świadczenie rentowe na poziomie płacy minimalnej w gospodarce. Została mu przyznana przez sąd renta miesięczna w wysokości 1600 PLN (z tytułu utraty dochodów i zwiększenia wydatków²). W symulacji przyjęto, że przewidywany dalszy czas trwania życia tego mężczyzny wynosi 27 lat, co skutkuje 324 miesięcznymi wypłatami.

Rys. 4 prezentuje różnicę w kształtowaniu się wartości realnej renty zasądzonej i teoretycznej.

${ }^{2}$ W wyroku sądowym brak informacji pozwalających na określenie, jaka część przyznanej kwoty odpowiada utraconym dochodom. W dalszej części symulacji posłużono się pełną kwotą przyznanego świadczenia. 


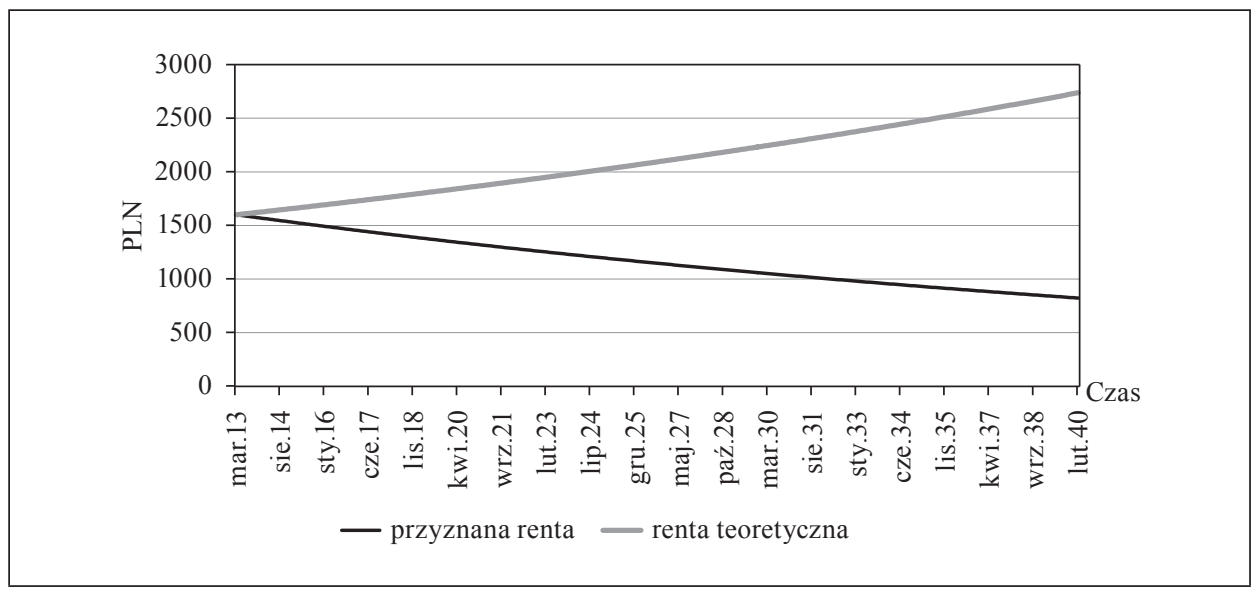

Rys. 4. Wartość realna renty dożywotniej (przypadek 2)

Źródło: opracowanie własne.

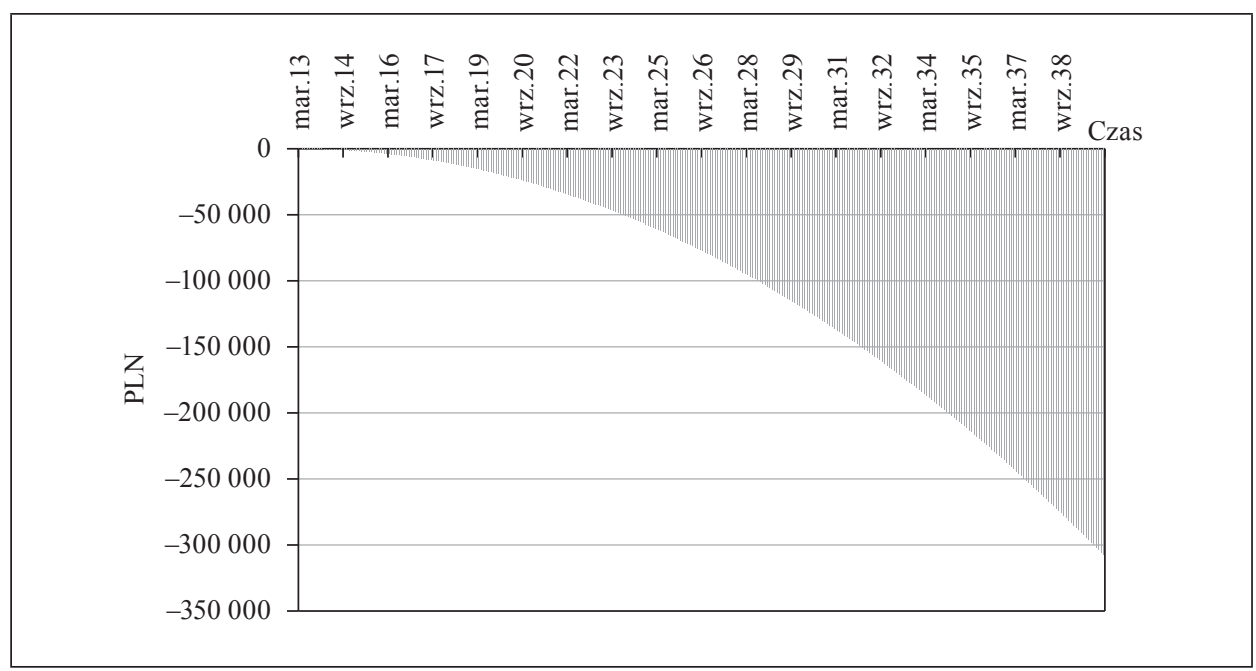

Rys. 5. Skumulowany niedobór z tytułu przyznanej renty (przypadek 2) Źródło: opracowanie własne.

W tym przykładzie wartość obecna zasądzonego świadczenia rentowego wyniosła 378751 PLN w stosunku do teoretycznego świadczenia rentowego, którego wartość obecna wyniosła 686369 PLN. Różnica w wartościach obecnych sięgnęła zatem kwoty 307618 PLN. Narastanie tego niedoboru można prześle- 
dzić na rys. 5 . W tym przypadku również zauważalne jest znaczne pogorszenie się standardu życia gospodarstwa domowego poszkodowanego.

\section{Przypadek 3}

Przypadek 3 dotyczy nowo narodzonego dziecka, w imieniu którego złożono wniosek o rentę miesięczną równą połowie średniego miesięcznego wynagrodzenia $\mathrm{w}$ sektorze przedsiębiorstw. W wyniku postępowania sądowego została przyznana renta miesięczna w wysokości 1317 PLN (z tytułu utraty dochodów i zwiększenia wydatków ${ }^{3}$ ). W symulacji przyjęto szacowaną liczbę miesięcy wypłat renty w liczbie 864, co odpowiada przewidywanym 72 latom życia noworodka.

Rys. 6 pokazuje rozbieżność między wartościami realnymi zasądzonej i teoretycznej renty (podlegającej indeksowaniu). Wynika to z najdłuższego przewidywanego czasu wypłaty świadczenia wynoszącego 72 lata. Wartość ostatniej obliczonej wypłaty w ujęciu realnym bez indeksacji wyniosła jedynie 223 PLN w stosunku do kwoty 5533 PLN (realna wartość teoretycznej renty indeksowanej).

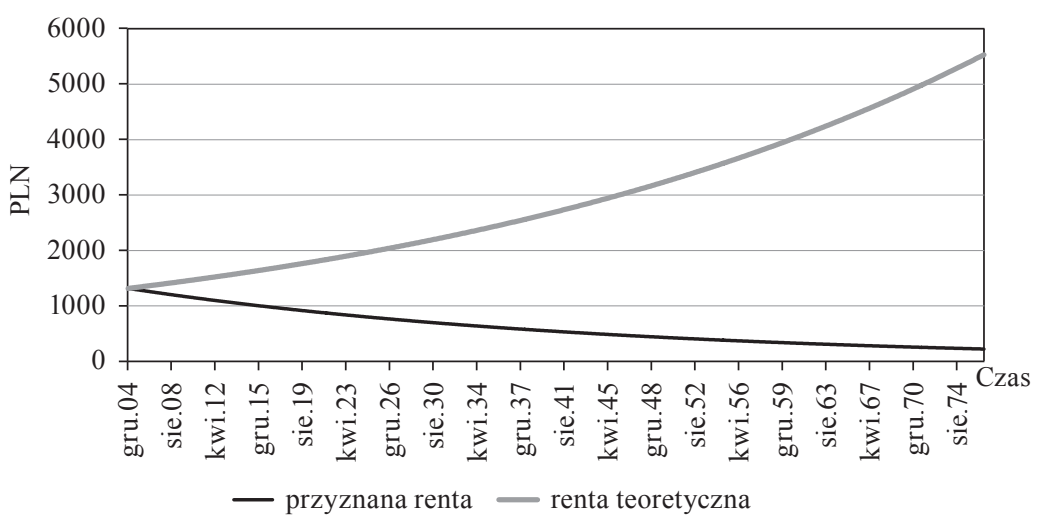

Rys. 6. Wartość realna renty dożywotniej (przypadek 3)

Źródło: opracowanie własne.

Wartość obecna teoretycznej renty z uwzględnieniem indeksacji sięga poziomu 2538119 PLN, natomiast wartość obecna renty bez indeksacji jest 5-krotnie niższa i wynosi tylko 532413 PLN. Przykład ten dobitnie pokazuje,

${ }^{3}$ Podobnie jak w przykładzie 2 kwota ta nie została podzielona na rentę z tytułu utraty dochodów i zwiększonych wydatków. 
jak duże znaczenie dla poszkodowanych ma indeksowanie ich świadczenia rentowego, szczególnie gdy odnosi się do ludzi młodych. W rozpatrywanym przypadku niedobór przekroczył kilkakrotnie wartość przyznanego świadczenia i wyniósł 2005706 PLN (por. rys. 7).

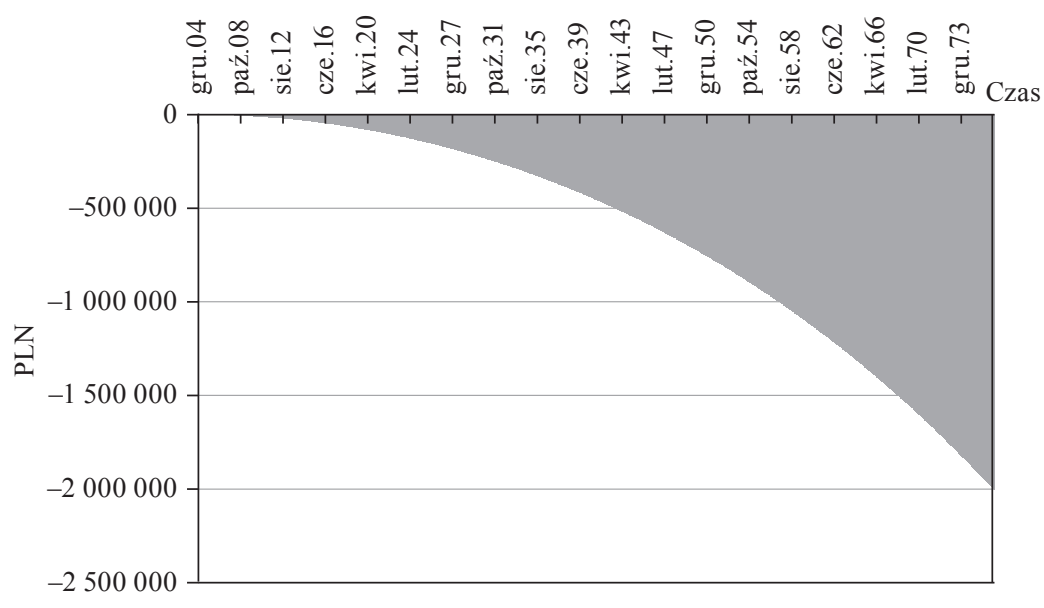

Rys. 7. Skumulowany niedobór z tytułu przyznanej renty (przypadek 3)

Źródło: opracowanie własne.

\section{Wnioski końcowe}

Zaprezentowane rozważania teoretyczne, jak również przeprowadzone symulacje wskazują na potrzebę zmiany dotychczasowej praktyki przyznawania odszkodowawczych świadczeń rentowych z tytułu utraconych dochodów. Praktyka niewaloryzowania świadczenia przez sądy prowadzi do szybkiego realnego obniżenia wartości przyznanej renty, a co za tym idzie - do szybkiego obniżania się standardu życia poszkodowanego. Taka sytuacja może powiększać odczucie doznanej krzywdy przez poszkodowanego w związku utratą przez niego możliwości partycypacji we wzroście gospodarczym i zwiększaniu realnego poziomu dochodów tak jak reszta społeczeństwa. Różnica w wartościach obecnych świadczeń odszkodowawczych jest szczególnie dotkliwa w przypadku poszkodowanych osób małoletnich. Zaniżenie świadczenia może być w tym przypadku kilkakrotne.

W celu uniknięcia tych rozbieżności należy kapitalizować świadczenia rentowe. Waloryzacja powinna obejmować nie tylko realne utrzymanie ich 
wartości, ale również uwzględniać wzrost wynagrodzeń w gospodarce, aby utrzymać standard życia poszkodowanego w stosunku do reszty społeczeństwa. Winno się zatem uwzględniać tempo wzrostu świadczenia na poziomie możliwym do osiągnięcia przez poszkodowanego, gdyby kontynuował lub podjął on pracę zarobkową. Można również stwierdzić, że renta przyznana z pominięciem waloryzacji świadczenia nie spełnia swojej funkcji, którą jest subsydiowanie utraconych przez poszkodowanego dochodów, jej wartość bowiem znacząco (w późniejszych latach jej wypłacania) odbiega od wartości dochodów, które powinna zastępować.

\section{Literatura}

Anderson G.A., Roberts D.L. [1989], Stability in the Present Value Assessment of Lost Earnings, ,Journal of Risk and Insurance”, vol. 56(1).

Bryan W., Linke C.M. [1988], The Estimation of the Age/Earnings Profiles in Wrongful Death and Injury Cases: Comment, „The Journal of Risk and Insurance”, vol. 55(1).

Gilbert R.F. [1994], Estimates of Earnings Growth Rates Based on Earnings Profiles, „Journal of Legal Economics”, vol. 4(2).

Gilbert R.F. [1997], Long-term and Short-term Changes in Earnings Profiles, „Journal of Forensic Economics", vol. 10(1).

Gohmann S.F., McCrickard M.J., Slesnick F. [1998], Age-earnings Profiles Estimates: Do They Change over Time?, „Journal of Forensic Economics”, vol. 11(3).

Haberman S., Bloomfield D. [1990], Work Time Lost to Sickness, Unemployment and Stoppages: Measurement and Application, „Journal of the Institute of Actuaries”, vol. 117(3).

Kucsma K.K., Tinari F.D. [2010], Assessing Economic Damages in Personal Injury and Wrongful Death Litigation: The State of New Jersey, ,Journal of Forensic Economics", vol. 21, nr 2, June, http://www.tinarieconomics.com/sites/default/files/pdfs/ assessing_economic_damages.pdf (dostęp: 3.04.2015).

Lane J., Glennon D. [1985], The Estimation of Age/Earnings Profiles in Wrongful Death and Injury Cases, „Journal of Risk and Insurance”, vol. 52(4).

Lewis R., McNabb R., Robinson H., Wass V.J. [2002], A Comparison of Two Alternative Methods for Determining Loss of Future Earnings in Personal Injury Cases, Presented at Royal Economic Society Annual Conference 2002, Warwick, UK, 25-27 March.

Luckett N., Craner J. [1994], Multipliers: Are the Courts Being Fair to Claimants?, „Journal of Personal Injury Litigation", nr 5.

Minnchan R. [2009], Examples of "Schedules of Damages" Used in Europe and the United States [w:] Personal Injury and Wrongful Death Damages Calculations: Transatlantic Dialogue, red. J.O. Ward i R.J. Thornton, „Contemporary Studies in Economic and Financial Analysis", vol. 91(2009).

Mullet M.J., Nelson D.M., Patton R.T. [1990], Alternative Measures of Earnings Growth, „Journal of Forensic Economics”, vol. 3(1).

Nelson D.M., Patton R.T. [1990], Measuring Earnings Growth in the U.S., ,Journal of Legal Economics", vol. 3(3). 
Ritchie D. [1994], Smith v Manchester Awards: How Do Courts Assess Loss of Capacity on the Labour Market, ,,Journal of Personal Injury Litigation”.

Rodgers J.D., Brookshire M.L., Thornton R.J. [1996], Forecasting Earnings Using Age-earnings Profiles and Longitudinal Data, ,Journal of Forensic Economics”, vol. 9(2).

Smith S.J. [1982], New Worklife Estimates Reflect Changing Profile of Labor Force, „Monthly Labor Review”, vol. 105(3).

Spizman L., Tinari F.D. [2011], Assessing Economic Damages in Personal Injury and Wrongful Death Litigation: The State of New York, „Journal of Forensic Economics”, vol. 22, nr 1, June, http://www.tinarieconomics.com/sites/default/files/pdfs/Assessing\%20Economic\%20Damages\%20in\%20NY\%20\%28jfe.22.1.75\%29.pdf (dostęp: 3.04.2015).

Thornton R.J., Rodgers J.D., Brookshire M.L. [1997], On the Interpretation of Age-earnings Profiles, ,Journal of Labour Research”, vol. 18(2).

Tinari F., Cahill K.E., Grivoyannis E. [2006], Did the 9/11 Victim Compensation Fund Accurately Assess Economic Losses?, „Topics in Economic Analysis and Policy”, vol. 6, nr 1, January, http://www.tinarieconomics.com/sites/default/files/Victim\%20 Compensation\%20Fund.pdf (dostęp: 5.04.2014).

Ward J.O. [2009], Economic Damages and Tort Reform: A Comparative Analysis of the Calculation of Economic Damages in Personal Injury and Death Litigation in the United States and the United Kingdom [w:] Personal Injury and Wrongful Death Damages Calculations: Transatlantic Dialogue, red. J.O. Ward i R.J. Thornton, „Contemporary Studies in Economic and Financial Analysis”, vol. 91, http://www. emeraldin-sight.com/books.htm?chapterid=1819487 (dostęp: 5.04.2014).

\section{Adjustment of Compensation for Loss of Earnings Using Future Wage Forecasts}

(Abstract)

The compensation that should be given to injured individuals is made up of several elements. When the victim is unable to work, income he or she has lost is compensated. To properly establish that compensation, two factors are considered: time value of money and the rate of growth of wages in the sector where the victim worked. Inflation should also be figured in.

The article presents simulations of different approaches - ones that do not take these factors into account, and others that do. The first approach is often used by the Polish justice system in determining the amount of pension compensation, while the second is a proposal to better protect victims who have lost the ability to work.

Keywords: annuity, compensation, personal finance, personal injured. 